\title{
Student Learning Result of Citizenship Education in Internet Learning Media with High Interpersonal Communication in High School Al-Azhar Medan
}

\author{
Ronald Hamonangan Panggabean ${ }^{1}$, Julaga Situmorang ${ }^{2}$, Samsidar Tanjung ${ }^{2}$ \\ ${ }^{1}$ Master Student in Universitas Negeri Medan (Unimed), Medan, Indonesia \\ ${ }^{2}$ Lecturer in in Universitas Negeri Medan (Unimed), Medan, Indonesia \\ ronald.gabe22@gmail.com
}

\begin{abstract}
: the aim of this research is to get a student learning result of citizenship education in internet learning media with high interpersonal communication get solustion for problems about the teaching and learning process in Civics learning in this school, the researcher conducted a direct interview with the teacher who took care of the subjects to the location/ object of research, namely class XI teacher Al-Azhar High School Medan. This research was conducted at Al-Azhar High School Medan, in class XI, both for conducting instrument trials and conducting research. This research will be carried out in the even semester of 2018/2019 Academic Year, namely in April 2019, with the treatment given in 6 meetings. The result is Interpersonal communication is communication between communicator and communicant and Citizenship learning outcomes of students who have high interpersonal communication are higher than citizen ship learning outcomes of students who have low interpersonal communication.
\end{abstract}

Keywords: Interpersonal Communication; Learning Media; internet.

\section{Introduction}

Pancasila and Citizenship Education are subjects studied by all students from Elementary Schools (SD) to High Schools (SMA) and even in Higher Education. Pancasila and Citizenship Education subjects need to be delivered to all students ranging from elementary school to high school to equip students with social skills so that students have moral, character in the midst of society.

Based on data obtained from a list of grades (DKN) of class XI students of Al-Azhar Medan High School for the 2015/2016 Academic Year an average score of 70 students was obtained. While in the 2016/2017 Academic Year the final report of students for Civics subjects obtained grades average student 72 . This average score is still below the average minimum completeness of the citizen ship subject of Al-Azhar High School Medan subjects with an average grade of 75 . These data indicate that the acquisition of Civics learning outcomes is still very low.

Table 1. Al Azhar High School Learning Result

\begin{tabular}{|l|l|c|c|}
\hline \multicolumn{2}{|c|}{ Academic Year } & $\begin{array}{c}\text { Average Civics } \\
\text { Learning Outcomes }\end{array}$ & KKM \\
\hline $2015 / 2016$ & Semester I & 70 & 75 \\
\cline { 2 - 4 } & Semester II & 65 & 75 \\
\hline \multirow{2}{*}{$2016 / 2017$} & Semester I & 73 & 75 \\
\cline { 2 - 4 } & Semester II & 60 & 75 \\
\hline $2017 / 2018$ & Semester I & 70 & 75 \\
\cline { 2 - 4 } & Semester II & 72 & 75 \\
\hline
\end{tabular}

Source: Al Azhar High School Documents 
To get a clear picture and problems about the teaching and learning process in Civics learning in this school, the researcher conducted a direct interview with the teacher who took care of the subjects to the location object of research, namely class XI teacher Al-Azhar High School Medan. From the results of the author's interview with the teacher, information was obtained that the difficulties faced by the teacher in teaching civics studies include: (1) low interpersonal communication; (2) Teachers are less able to motivate students to learn actively and seriously in the classroom, so that students do not concentrate too much following the learning process; (3) The teacher recognizes that the learning media used in Civics subjects so far generally only use conventional media; (4) Students are less motivated to follow the subject matter because the learning media used in the delivery are always monotonous; the application of this monotonous learning media is thought to be one of the factors causing the low student grades for Civics in the XI class of Al-Azhar High School Medan; (5) The teacher only holds the subject matter that is in the student manual and worksheet; (6) teaching and learning activities are centered on the teacher (teacher centered) while students are more passive; and (7) Students seem bored or bored in following the learning process in class and tend to lose their critical, innovative and creative reasoning power.

The still low student Civics Learning outcomes as expressed above, are inseparable from the influence of various factors in learning activities, both students' internal and external factors. Internal factors that are thought to influence learning outcomes include interpersonal communication, while external factors that are thought to influence it include student learning environments, teacher abilities, facilities and facilities / media, and learning strategies used by teachers.

\section{Literature review}

\subsection{The Nature of Learning Outcomes}

According to Gagne (1988) learning occurs when a stimulus situation along with the contents of memory affects students in such a way that their actions change from the time before he experienced the situation to the time after he experienced the situation earlier. According to Purwanto (2007: 84) learning related to changes in a person's behavior towards a particular situation caused by repeated experiences in that situation, where changes in behavior are not explained or the basis of a person's response, maturity or circumstances. According Pidarta (2009: 206) learning is a change in behavior that is relatively permanent as a result of experience (not the result of development, the influence of drugs, or accidents) and can implement it on other knowledge and be able to communicate it to others. Slameto (2010: 2) argues learning is a business process carried out by someone to obtain a new change in behavior as a whole, as a result of his own experience in interaction with the environment. These changes will be evident in all aspects of a person's behavior, both changes in themselves and in everyday life.

\subsection{Learning Media}

When viewed from the history of the teacher, at first the teacher became the only source for obtaining lessons, then in subsequent developments a printing press was found that could produce books as study material. Teaching experts like Sardiman (2012: 7) define learning media as something that can be used to channel messages from the sender to the recipient so that they can stimulate the thoughts, feelings, attention and motivation and attention of students in such a way that the learning process occurs. Media is a tool that must be there to make things 
easier for work. Specifically, Sharon put forward the notion of media (2005: 9) " A medium (plural, media) is a means of communication and source of information ". The media is a means of communication and information sources. According to Rohani (1997: 3) "Media is everything that can be sensed that functions as an intermediary/facility/tool for the communication process".

Rohani (1997: 4) provides a limitation of instructional media is a means of communication in the teaching and learning process in the form of hardware and software to achieve the process and learning outcomes effectively and efficiently, as well as learning objectives can be achieved easily. Azhar (2013: 19) "The use of instructional media in teaching and learning can arouse new interests and desires, arouse motivation and stimulation of learning activities and even bring new psychological influences on students." From this presentation the learning media can increase desires and bring psychological impacts and increase learning motivation for students. Azhar (2013: 3) "Media is a tool that conveys or delivers learning messages. More specifically learning media are graphic, photographic or electronic tools for capturing, processing and rearranging visual or verbal information. "Based on the description above, it can be concluded that what is meant by learning media is a tool used by the instructor to convey the material's message to students. Through good learning media the teacher can convey information about the subject matter concerned.

\subsection{Internet Learning Media}

Internet stands for interconnection and networking. The internet is the largest global information network that allows people to interact easily and quickly through technology, especially Personal Computers (PCs). The internet was first launched by JCR Licklider of Massachusetts Institute Technology (MIT) in August 1962. The term internet, if translated directly means a network that is connected to one another. The internet itself is a combination of computer networks around the world that form a global information network system.

It cannot be denied that the internet includes social networking, both directly and indirectly having an impact on society, both positive and negative. The impact is not limited to certain circles, but has expanded to all circles both educated and non-educated circles. As an institution that is directly related to daily life, educational institutions too, in this case schools, do not miss utilizing the function of the internet in the process of education and learning in the classroom. "Although the Internet is physically an interconnection between computer networks, in general the Internet must be seen as an information resource. Internet content is information, can be imagined as a database or multi-media library that is very large and complete. Even the Internet is seen as a world in other forms (virtual) because almost all aspects of life in the real world there are 25 online such as business, entertainment, sports, politicsand so on. "Lani Sidharta (1996) Another function of the internet is as a tool or media in teaching and learning process in class. With the available facilities, it is not surprising that the internet has become a way of life for some people, including students. Most of the reasons students use the internet are to do the work of the teacher. Therefore in the world of education, the internet provides an access to data that can facilitate the teaching and learning process.

Learning media that are used are sources that are not specifically designed for learning purposes but can be found, applied and used for learning purposes. From some definitions and explanations about instructional technology, it can be concluded that instructional technology produces learning media that can be used to improve teaching. There are certain functions, for example instructional development, media production, management of learning media, 
program evaluation, and so on which must be carried out by certain personnel in the field of instructional technology.

The internet as a learning medium that is utilized can provide learning facilities for students because the internet is a worldwide computer information network that is growing very rapidly and at this time can be said to be the largest information network in the world, so it should professionals know what benefits can be obtained through this network. The learning process in the classroom that uses the internet as a learning medium is expected to be part of a learning process at school, the internet is expected to be able to provide support for the implementation of an interactive communication process between teachers and students. Conditions that need to be supported by the internet are related to learning media that will be developed, namely as a communication activity undertaken to invite students to work on assignments and assist students in gaining the knowledge needed in order to do the assignments. All computers connected to the internet can access all information contained on the internet for free. The internet can be used as a means of exchanging information from one computer to another without being limited by the physical distance of the two computers. The very important role of the internet is as a source of data and information and as a means of exchanging data and information.

\subsection{Interpersonal Communication}

Communication between the personal is the communication that takes place in a situation of face-to- face between two people or more. Both are in the organized and the crowd of people.Interpersonal communication is a person-to-person interaction, both ways, verbal and non-verbal.Sharing information and feelings between individuals and individuals or between individuals in small groups.

According to DeVito (1989), communication interpersonal is the delivery of a messagebyone person and receipt of a message by another person or a group of little people, with a variety of effects and with the opportunity to provide feedback immediately (Effendy, 2003: 30). Communication interpersonal is communication between people in face-to- face, which allowseach participant capture reactions of others are directly. It is either by verbal or nonverbal.Communication interpersonal this is a communication that only two people, such as a husband a wife, two colleagues, twofriends close, teacher- pupil and so on.

According to Effendi, interpersonal communication is essentially communication between communicator and communicant, this type of communication is considered to be the most effective in changing one's attitude, opinion or behavior, because of its dialogical nature in the form of conversation. Reverse flow is direct, the communicator knows the communicant's response right away. When communication is carried out, the communicator knows for certain whether the communication is positive or negative, successful or not. If he can provide the opportunity for the communicant to ask as broadly as possible Interpersonal Communication Between Two People is communication from one person to another, two-way verbal and nonverbal interactions that involve sharing information and feelings.

\section{Research Methodology}

This research was conducted at Al-Azhar High School Medan, in class XI, both for conducting instrument trials and conducting research. This research will be carried out in the 
even semester of 2018/2019 Academic Year, namely in April 2019, with the treatment given in 6 meetings. For one meeting, it takes $2 \times 45$ minutes.

Population is a whole unit that has the same characteristics. In other words, the population is an entire unit that is equipped with the characteristics of the problem under study (Sitorus, 2011: 44).

In this study the authors determined that the study population were all students of Al-Azhar Medan High School class XI. The total population is 199 students in 2018/2019 Academic Year consisting of 5 classes. The distribution of students in the 5 classes is not grouped in the ranking and grouping of superior classes but the distribution of students into the 5 classes is done randomly when placing students in their respective classes. Population distribution can be seen in table 2 below:

Table 2. Distribution of Class XI Students at Al-Azhar High School Medan Academic Year 2018/2019

\begin{tabular}{|c|c|c|c|}
\hline \multirow{2}{*}{ Class } & \multicolumn{2}{|c|}{ Total students } & \multirow{2}{*}{ Amount } \\
\cline { 2 - 3 } & LK & Homework & \\
\hline XI A & 21 & 20 & 41 \\
\hline XI B & 20 & 18 & 38 \\
\hline XI C & 20 & 20 & 40 \\
\hline XI D & 20 & 19 & 39 \\
\hline XI E & 21 & 20 & 41 \\
\hline \multicolumn{3}{|c|}{ Amount } \\
\hline
\end{tabular}

Source: Student Statistics Data TP 2018/2019

\section{Discussion}

Based on the scores of Civics learning outcomes variables in the Internet Learning Media class with High Interpersonal Communication collected, spread of the largest number of scores 100 and the smallest 68, with Mode $(\mathrm{Mo})=89.16$; Median $(\mathrm{Me})=88.63$; Mean $=88$. The frequency distribution of Civics learning outcomes in the Internet Learning Media class with High Interpersonal Communication can be seen in Table 3. While the histogram image of the data can be seen in Figure 1.

Table 3. Frequency Distribution of Civics Learning Outcomes Scores in Internet Learning Media Classes with High Interpersonal Communication

\begin{tabular}{|l|l|c|c|}
\hline No & Interval Class & $\begin{array}{l}\text { F absolute } \\
\text { frequency }\end{array}$ & $\begin{array}{l}\text { Relative } \\
\text { frequency (\%) }\end{array}$ \\
\hline 1 & $68-72$ & 1 & 3.44 \\
\hline 2 & $73-77$ & 2 & 6.89 \\
\hline 3 & $78-82$ & 2 & 6.89 \\
\hline 4 & $83-87$ & 7 & 24,13 \\
\hline 5 & $88-92$ & 11 & 37.93 \\
\hline 6 & $93-97$ & 3 & 10,34 \\
\hline 7 & $98-102$ & 3 & 10,34 \\
\hline & & $\mathbf{2 9}$ & $\mathbf{1 0 0 \%}$ \\
\hline
\end{tabular}


Table 3 shows that the average grade is in the interval class 88 - 92 with a total of 11 people (37.93\%). Students with scores below the average numbered 12 people (41.35\%) and students with scores above the average numbered 6 people $(20.68 \%)$. Furthermore, it can be described frequency distribution histogram score at grade civics learning outcomes Learning Media Center with High Interpersonal Communication as Figure 1

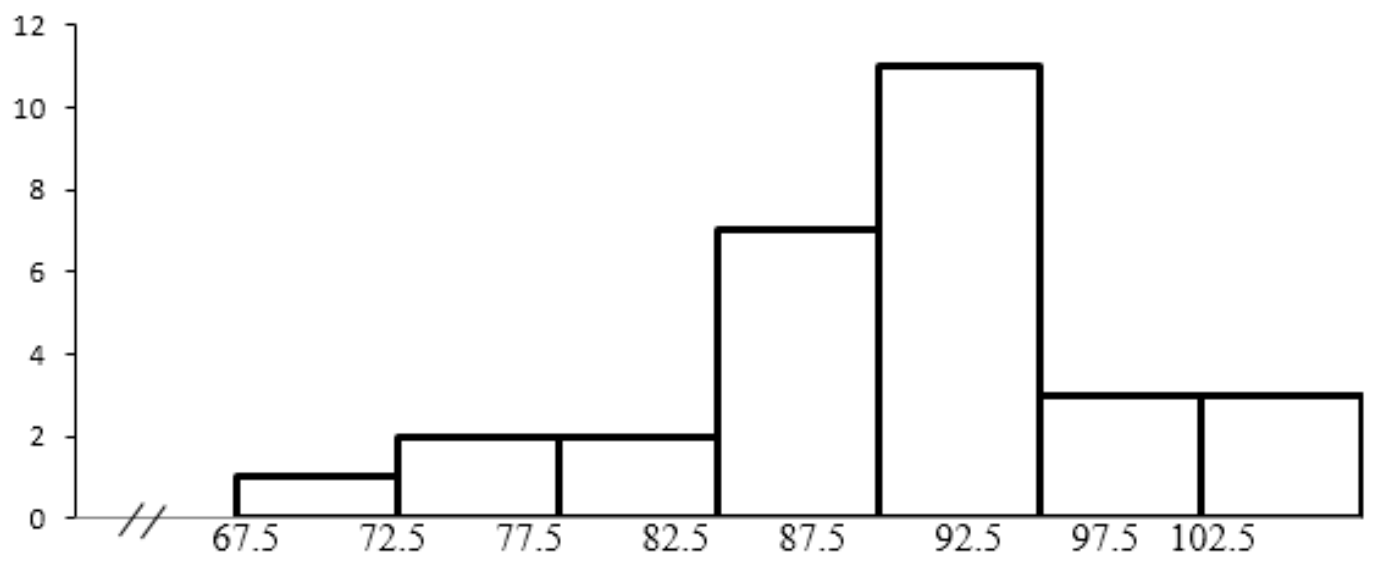

Figure 1. Histogram Score Civics at Grade Learning Outcomes Learning Media Center with Interpersonal Communication High

Checking the normality of the data is used to determine whether the sample is from a normally distributed population. The test is carried out using $\mathrm{L}_{\text {count }}<\mathrm{L}_{\text {tabel }}$ test on fourteen groups of samples and if $\mathrm{L}_{\text {counts }}<\mathrm{L}_{\text {table }}$ then the data is normally distributed. Complete calculations can be seen in the appendix. A summary of the results of normality calculations can be seen in the following table 4.9

Tabel 4. Summary of Calculation Results for Data Normality

\begin{tabular}{|l|l|l|l|}
\hline Group & $\mathbf{L}_{\text {count }}$ & $\mathbf{L}_{\text {table }}$ & Information \\
\hline $\begin{array}{l}\text { Results Learning Civic Education in } \\
\text { the Classroom Instructional Media } \\
\begin{array}{l}\text { Center and Interpersonal } \\
\text { Communication High }\end{array}\end{array}$ & 0,133 & 0,161 & Normal \\
\hline
\end{tabular}

Homogeneity variance test is performed to determine whether the sample variant comes from a homogeneous population or not. The homogeneity test was conducted with the fisher test and barlet test to compare the variants of student Civics learning outcomes data between internet learning media and module learning media as well as high interpersonal communication and low interpersonal communication. Complete calculations can be seen in the appendix and if $\mathrm{F}_{\text {count }}<\mathrm{F}_{\text {table }}$ then the data is homogeneous. The summary of homogeneity test calculation of internet learning media groups and learning media modules is shown in table.5.

Table 5. Summary Analysis of Homegeneity Test Data

\begin{tabular}{|l|l|l|l|l|}
\hline \multicolumn{1}{|c|}{ Sample Group } & Group & \multicolumn{1}{c|}{ F count } & \multicolumn{1}{c|}{ F table } & Explanation \\
\hline $\begin{array}{l}\text { Citizenship Learning Result } \\
\text { in High Interpersonal }\end{array}$ & 2 & 1.53 & 1.71 & Homogeneous \\
\hline
\end{tabular}




\begin{tabular}{|l|l|l|l|l|}
\hline $\begin{array}{l}\text { Communication Class (B1) } \\
\text { and Low Interpersonal } \\
\text { Communication (B2) }\end{array}$ & & & & \\
\hline
\end{tabular}

Hypothesis testing is done to prove the assessment of the hypothesis that has been set so that it is obtained whether the hypothesis designed in the study is accepted or rejected. For the purposes of submitting hypotheses $2 \times 2$ Anava factorial technique was used and then continued with Scheffe further tests. The following table 6 presents a summary of student learning outcomes learning Civics as a source of data processing for hypothesis testing.

Table 6. Summary of Data Results of Descriptive Analysis Calculations

\begin{tabular}{|c|c|c|c|c|}
\hline \multirow{2}{*}{\multicolumn{2}{|c|}{ Data Summary }} & \multicolumn{2}{|l|}{ Learning Media } & \\
\hline & & Internet & Module & \\
\hline $\begin{array}{l}\text { Interpersonal } \\
\text { communication }\end{array}$ & High & $\begin{array}{l}\mathrm{N}=29 \\
\bar{x}=88 \\
\sum x=2550 \\
\sum x^{2}=225700\end{array}$ & $\begin{array}{l}\mathrm{N}=26 \\
\bar{x}=86,11 \\
\sum x=2239 \\
\sum x^{2}=195196\end{array}$ & $\begin{array}{l}\mathrm{N}=55 \\
\bar{x}=88 \\
\sum x=4833 \\
\sum x^{2}=428503\end{array}$ \\
\hline
\end{tabular}

Then the results of the analysis are obtained as shown in table 7 .

Table 7. Summary of Analysis of Variance Learning Results of Citizenship Subject

\begin{tabular}{|l|l|l|l|l|l|l|}
\hline Variant Resources & dk & JK & RJK & F counts & F table & Information \\
\hline Learning Method (A) & 1 & 74.88 & 74.88 & 9.34 & 3,9 & Significant \\
Learning Style (B) & 1 & 77.49 & 77.49 & 9.67 & 3.9 & Significant \\
Interaction (AB) & 1 & 83.53 & 83.53 & 10,42 & 3.9 & Significant \\
Error & 75 & 625 & 8.01 & & & \\
\hline & $\mathbf{7 8}$ & $\mathbf{8 6 0 , 9}$ & & & & \\
\hline
\end{tabular}

\section{Conclusions}

Citizenship learning outcomes of students who have high interpersonal communication are higher than citizen ship learning outcomes of students who have low interpersonal communication.

Interpersonal communication is communication between communicator and communicant, this type of communication is considered the most effective way in changing one's attitude, opinion or behavior, because of its dialogical nature in the form of conversation. Reverse flow is direct, the communicator knows the communicant's response right away. When communication is carried out, the communicator knows for certain whether the communication is positive or negative, successful or not. If he can provide the opportunity for the communicant to ask as broadly as possible Interpersonal Communication Between Two People is communication from one person to another, two-way verbal and nonverbal interactions that involve sharing information and feelings. 


\section{References}

Anderson, L. W. and Krathwohl, D. R.. 2010. Teaching and Assessing: ARevision of Bloom's Taxonomy of Educational Objectives, terj. Agung Prihantoro, Kerangka Landasan Untuk Pembelajaran, Pengajaran, dan Asesmen: Revision of Taksonomi Pendidikan Bloom, Yogyakarta: Pustaka Pelajar.

Anwar, Q. 2003, Pendidikan Sebagai Karakter Budaya Bangsa, Jakarta: UHAMKA Press. Arikunto, S. 2013, Dasar-Dasar Evaluasi Pendidikan, Jakarta: Bumi Aksara, Edition. 2. . 2010. Prosedur Penelitian; Suatu Pendekatan Praktik. Jakarta: Rineka Cipta.

Atmowidjoyo,S. 2008. Perencanaan Sistem Instruksional, Jakarta: Universitas Islam Jakarta. Bloom, B. S. 1979. Taxonomy of Educational Objectives. London: Longman.

Buckhori, M. 2006. Pendidikan Antisipatoris, Yogyakarta: Kanisius, Edition. 6.

Bungin, M. B. 2011. Metodologi Penelitian Kuantitatif. $6^{\text {th }}$ edition. Jakarta: Kencana Prenada Media.

Chance, P. 1979. Learning and Behavior, California: Wadsworth Publishing Company, Inc.

Danim, S. 2007. Visi Baru Manajemen Sekolah; Dari Unit Birokrasi keLembaga Akademik, Jakarta: Bumi Aksara, Edition. 2.

Davies, I. K. 1981. Instructional Technique, New York: McGraw-Hill Book Company.

.1987. The Management of Learning,Translation. Sudarsono Sudirdjo, Pengelolaan Belajar; Seri Pustaka Teknologi Pendidikan No. 8, Jakarta: Rajawali Press.

Davis, R. H. A. 1990. Learning System Design, An Approach to theImprovement of Instruction, New York: Mc Graw-Hill Book Company.

Dick, W. 2005. The Systematic Design of Instruction, 6th ed., Boston: Pearson.

Gagne, R. M. 1985. The Conditions of Learning and Theory of Instruction, New York: Holt, Rinehart, and Winston.

. 1979. Principles of Intructional Design, Second Edition, New York: Holt, Rinehart and Winston.

Galloway, C. 1976. Psychology for Learning and Teaching, New York: McGraw-Hill Book Company.

Gredler, M. E. 2011. Learning and Instruction: Theory into Practice, translation. Tri Wibowo

B.S., Learning and Instruction: Teori dan Aplikasi, Jakarta: Kencana Prenada Media, Edition. 1,.

Hamalik, O. 2009. Proses Belajar Mengajar, Jakarta: Bumi Aksara. 1996. Strategi Belajar Mengajar, Bandung: Mandar Madju.

Hamdani. 2011. Strategi Belajar Mengajar, Bandung: Pustaka Setia.

Hergenhahn, B.R. 2008 Theory of Learning TeoriBelajar, translation. Tri Wibowo B.S., Jakarta: Kencana Prenada Media, Edition. 1.

Hurlock, E. B. 1980. Development Psychology: A Life-Span Approach,Fifth Edition, terj. Istiwidayanti dan Soedjarwo, Psikologi Perkembangan: Suatu Pendekatan Sepanjang Rentang Kehidupan, 5st Edition, Jakarta:Erlangga 